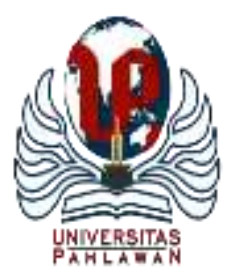

\title{
JURNALBASICEDU
}

Volume 5 Nomor 6 Tahun 2021 Halaman 6218 - 6226

Research \& Learningin Elementary Education

https://jbasic.org/index.php/basicedu

\section{Analisis Kebutuhan Bahan Ajar Mata Kuliah Kurikulum}

\author{
Eva Nurul Malahayati ${ }^{1 凶}$, Farida Nurlaila Zunaidah $^{2}$ \\ Universitas Islam Balitar, Indonesia ${ }^{1}$, Universitas Nusantara PGRI Kediri, Indonesia ${ }^{2}$ \\ E-mail: malahayatieva488@gmail.com ${ }^{1}$, farida@unpkdr.ac.id $^{2}$
}

\begin{abstract}
Abstrak
Ketersediaan bahan ajar dan sumber belajar adalah salah satu komponen penting dalam sebuah perkuliahan. Tujuan penelitian ini adalah menguraikan hasil angket kebutuhan bahan ajar oleh mahasiswa. Penelitian ini menggunakan metode deskriptif kualitatif. Responden sejumlah 66 mahasiswa dari Universitas Nusantara PGRI Kediri dan Universitas Islam Balitar. Instrument penelitian ini menggunakan angket analisis kebutuhan yang disajikan pada platform google form. Pengumpulan data dengan menyebarkan angket analisis kebutuhan bahan ajar pada 2 instansi yang berbeda. Teknik analisis data dengan menguraikan data hasil angket kebutuhan bahan ajar, yang dianalisis secara mendetail. Hasil pada penelitian ini adalah 1) mahasiswa membutuhkan sebuah bahan ajar berupa buku ajar untuk menunjang proses perkuliahan pada matakuliah kurikulum, 2) bahan ajar menyajikan topik-topik sesuai dengan yang disajikan dosen pengampu, 3) bahan ajar disajikan secara sistematis, menarik dan menggunakan Bahasa yang mudah dipahami oleh mahasiswa, dan 4) bahan ajar bisa bersifat fleksibel bisa diakses kapanpun dan dimanapun. Hasil analisis diharapkan dapat dijadikan dasar dalam mengembangkan bahan ajar kurikulum sesuai kebutuhan mahasiswa.
\end{abstract}

Kata Kunci: analisis, bahan ajar, mata kuliah kurikulum.

\begin{abstract}
The availability of teaching materials and learning resources is important components in a lecture. The purpose of this study is to describe the results of the questionnaire on the needs of teaching materials by students. This study uses a qualitative descriptive method The respondents were 66 students from Nusantara University, PGRI Kediri and Balitar Islamic University.. This research instrument uses a needs analysis questionnaire presented on the google form platform. Collecting data is by distributing an analysis of the needs of teaching materials in 2 different institutions. The technique of data analysis is to describe the data from the questionnaire on the needs of teaching materials, which are analyzed in detail. The result are 1) students need teaching materials in the form of textbooks to support the lecture process in curriculum subjects, 2) teaching materials present topics according to those presented by the lecturers, 3) teaching materials are presented in a systematic, interesting and use language which is easily understood by students and 4) teaching materials can be flexible and can be accessed anytime and anywhere. The results of the analysis are expected to be used as a basis for developing curriculum teaching materials according to student needs.
\end{abstract}

Keywords: analysis, teaching materials, curriculum courses

Copyright (c) 2021 Eva Nurul Malahayati, Farida Nurlaila Zunaidah

$\triangle$ Corresponding author :

Email : malahayatieva488@gmail.com

DOI $\quad$ : https://doi.org/10.31004/basicedu.v5i6.1802

ISSN 2580-3735 (Media Cetak)

ISSN 2580-1147 (Media Online)

Jurnal Basicedu Vol 5 No 6 Tahun 2021

p-ISSN 2580-3735 e-ISSN 2580-1147 
DOI: https://doi.org/10.31004/basicedu.v5i6.1802

\section{PENDAHULUAN}

Kurikulum merupakan seperangkat program pendidikan yang direncanakan dan tersusun secara sistematis serta dilaksanakan untuk mencapai mencapai tujuan-tujuan pendidikan (Fujiawati 2016). Kurikulum merupakan komponen penting dalam sebuah pendidikan. Kurikulum adalah pedoman dalam mencapai tujuan-tujuan yang telah direncanakan pada sebuh program pendidikan (Julaeha 2019). Tanpa adanya kurikulum pendidikan akan sulit mencapai target atau tujuan pendidikan yang telah diprogramkan. Mengingat pentingnya sebuah kurikulum dalam sebuah pendidikan, seyogyanya seorang pengajar perlu memahami apa itu kurikulum dan apa saja isi suatu kurikulum. Mengingat pengajar adalah subjek utama dalam pengimplementasian suatu kurikulum pendidikan (Sudrajat et al. 2020). Untuk menunjang hal tersebut maka para calon pengajar perlu mendapatkan bekal pengetahuan terkait kurikulum yang dikemas dalam sebuah matakuliah kurikulum.

Pada Fakultas Keguruan Dan Ilmu Pendidikan (FKIP) Universitas Balitar dan Universitas Nusantara PGRI Kediri pendalaman kurikulum dikemas dalam sebuah matakuliah Kajian Kurikulum, Telaah Kurikulum dan Pengembangan Kurikulum. Ketiga mata kuliah tersebut memiliki lingkup yang sama yakni sama-sama mempelajari lingkup komponen dan isi kurikulum pendidikan. Pelaksanaan perkuliahan perlu didukung berbagai sumber belajar untuk memperdalam pemahaman mahasiswa, salah satunya adalah bahan ajar berupa buku kurikulum. Buku-buku terkait kurikulum dibutuhkan untuk memperdalam pemahaman mahasiswa terkait kurikulum, serta sebagai penunjang dalam mengerjakan tugas terkait matakuliah. Menurut (Sasmita 2020) sumber belajar yang tepat akan mendukung tercapainya tujuan suatu pembelajaran. Sumber belajar sebenarnya tidak hanya berasal dari buku saja. Sumber belajar bisa berasal dari jurnal, artikel, majalah ilmiah, hasil wawancara, info berita, media massa dan lain-lain (Lilawati 2017). Meskipun bisa bersumber dari mana saja, tetap perlu adanya pemilihan sumber belajar yang tepat sesuai dengan materi perkuliahan yang dipelajari.

Berdasarkan hasil observasi yang dilakukan dengan mengamati perilaku belajar para mahasiswa diketahui bahwa banyak mahasiswa bingung dalam memilih sumber yang tepat. Sebenarnya sumber referensi berupa buku dan jurnal terkait kurikulum sudah diinformasikan kepada mahasiswa sejak kontrak perkuliahan dan tertulis dalam Rencana Perkuliahan Semester (RPS). Sumber buku terkait kurikulum juga sudah tersedia pada perpustakaan prodi. Namun mahasiswa banyak yang kesulitan memahami makna isi dalam buku-buku tersebut sehingga sering sekali bingung harus menentukan memakai buku yang tepat untuk membantu memahami materi serta membantu dalam mengerjakan tugas yang diberikan oleh dosen pengampu. Selain itu masalah juga muncul pada kurang terampilnya mahasiswa dalam mencari sumber belajar dari jurnal. Masalahmasalah tersebut membuat seakan-akan sumber belajar terkait kurikulum terbatas. Kemampuan mahasiswa dalam mencari sumber belajar dapat mempengaruhi hasil belajarnya (Hafid 2011). Kemampuan mencari sumber belajar yang tepat juga berpengaruh pada keterampilan menguraikan informasi yang didapat pada sumber belajar tersebut. Sehingga keterampilan dalam mencari dan menterjemahkan sumber belajar perlu untuk terus diasah (Supriadi 2015).

Permasalahan terkait keterampilan dalam mencari sumber belajar yang tepat, terdapat alternatif solusi dengan mengembangkan bahan ajar berupa buku ajar dasar-dasar kurikulum. Buku ajar merupakan buku yang disusun secara sistematis sesuai dengan bidang ilmu tertentu dan ditulis oleh pakar keilmuannya sebagai tambahan buku teks lain sebagai penunjang perkuliahan atau pembelajaran (Setiawan and Dores 2019). Buku ajar selain dapat digunakan oleh dosen untuk mengajar juga dapat digunakan sebagai referensi sumber belajar mahasiswa (Suwartini 2018). Buku ajar yang dikembangkan sendiri oleh dosen pengampu matakuliah memiliki kelebihan yakni dapat disesuaikan dengan kemampuan mahasiswa. Selain itu pengembangan buku ajar harus disesuaikan dengan kebutuhan mahasiswa dan ditulis dengan bahasa yang mudah dipahami oleh mahasiswa (Prasetiyo and Perwiraningtyas 2017). Kebutuhan mahasiswa akan buku ajar yang sesuai dengan 
DOI: https://doi.org/10.31004/basicedu.v5i6.1802

kebutuhannya akan mendukung sarana belajar mahasiswa baik secara terbimbing dalam kelas perkuliahan maupun secara belajar mandiri di luar kelas perkuliahan.

Seperti penelitian yang telah dilakukan oleh (Irawati and Saifuddin 2018) diketahui bahwa dengan pengembangan buku ajar akan berpengaruh terhadap kualitas belajar mahasiswa. Mahasiswa lebih antusias untuk belajar secara terbimbing maupun secara mandiri, karena memiliki sember belajar yang sesuai dengan kebutuhannya. Selain itu buku ajar yang dikembangkan juga dilengkapi dengan rangkuman materi dan soalsoal evaluasi agar dapat mengukur pemahaman mahasiswa dalam memahami tiap materi yang disajikan dalam buku ajar. Berdasarkan penelitian tersebut dapat dijadikan bahan referensi dalam penyusunan pengembangan buku ajar dasar-dasar kurikulum. Untuk itu perlu dilakukan analisis kebutuhan terlebih dahulu guna mengetahuai kebutuhan bahan ajar yang diinginkan mahasiswa. Analisis kebutuhan merupakan proses mencari atau menggali informasi terkait kebutuhan yang diharapkan, sebagai dasar dalam mengembangkan suatu produk (Wulandari and Purwanto 2017). Adanya hasil analisis kebutuhan ini akan membantu mengarahkan penyusunan buku ajar agar sesuai dengan kebutuhan mahasiswa. Diharapkan dengan adanya pengembangan buku ajar dasar-dasar kurikulum mampu meningkatkan motivasi belajar mahasiswa dan pemahaman mahasiswa terkait kurikulum.

\section{METODE PENELITIAN}

Penelitian ini menggunakan metode deskriptif kualitatif yakni dengan menguraikan data hasil penelitian yang didapat dari angket analisis kebutuhan bahan ajar. Subjek dalam penelitian ini adalah mahasiswa prodi biologi, PPKN, Pendidikan Bahasa Inggris, dan PGSD FKIP Universitas Islam Balitar dan Universitas Nusantara PGRI Kediri dengan jumlah keseluruhan 66 yang telah menempuh matakuliah kurikulum pada semester sebelumnya. Instrumen penelitian ini menggunakan angket analisis kebutuhan yang sebelumnya sudah divalidasi oleh 2 ahli materi yakni dosen yang pernah mengampu matakuliah kurikulum. Angket analisis kebutuhan disajikan pada platform google form untuk mempermudah penyebarluasan angket analisis kebutuhan kepada para mahasiswa. Angket menyajikan beberapa pertanyaan terkait kebutuhan bahan ajar pada matakuliah kurikulum. Pertanyaan tersebut terdiri atas:

1. Mata kuliah kurikulum apa yang sudah pernah Saudara/i tempuh?

2. Hal apa saja yang menjadi kendala dalam perkuliahan kurikulum?

3. Sumber belajar apa sajakah yang Saudara gunakan untuk mempelajari kurikulum ?

4. Apakah referensi dan bahan ajar yang ada saat ini sudah memenuhi kebutuhan Saudara/i dalam memahami kajian tentang kurikulum?

5. Jika ada pengembangan bahan ajar untuk mata kuliah tentang kurikulum, kriteria bahan ajar seperti apa yang Saudara/i inginkan? Sebutkan

6. Topik apa saja yang perlu ada dalam bahan ajar mata kuliah tentang kurikulum? Sebutkan

7. Bagaimana kriteria penyajian materi kurikulum dalam buku ajar yang Saudara/i butuhkan? Sebutkan

8. Latihan atau studi kasus seperti apa yang sesuai dalam mata kuliah kurikulum?

9. Apa saran saudara untuk pengembangan bahan ajar kurikulum agar mudah memahami kurikulum dan implementasinya?

Teknik pengumpulan data dengan menyebarkan angket analisis kebutuhan yang sudah divalidasi kepada para mahasiswa pada 2 instansi yang berbeda. Data hasil angket kemudian dijadikan bahan untuk dianalisis lebih lanjut. Teknik analisis data dengan menguraikan data hasil angket analisis kebutuhan. Data berupa prosentase dan uraian pendapat di deskripsikan secara mendalam untuk mendapatkan hasil berupa kesimpulan kebutuhan bahan ajar yang diinginkan mahasiswa. 
6221 Analisis Kebutuhan Bahan Ajar Mata Kuliah Kurikulum - Eva Nurul Malahayati, Farida Nurlaila Zunaidah

DOI: https://doi.org/10.31004/basicedu.v5i6.1802

\section{HASIL DAN PEMBAHASAN}

\section{Mata kuliah kurikulum apa yang sudah pernah Saudara/i tempuh?}

Pada angket analisis kebutuhan diawali dengan pertanyaan matakuliah kurikulum apa saja yang pernah ditempuh. Hasil dari ke 66 responden mahasiswa terangkum pada Gambar 1.

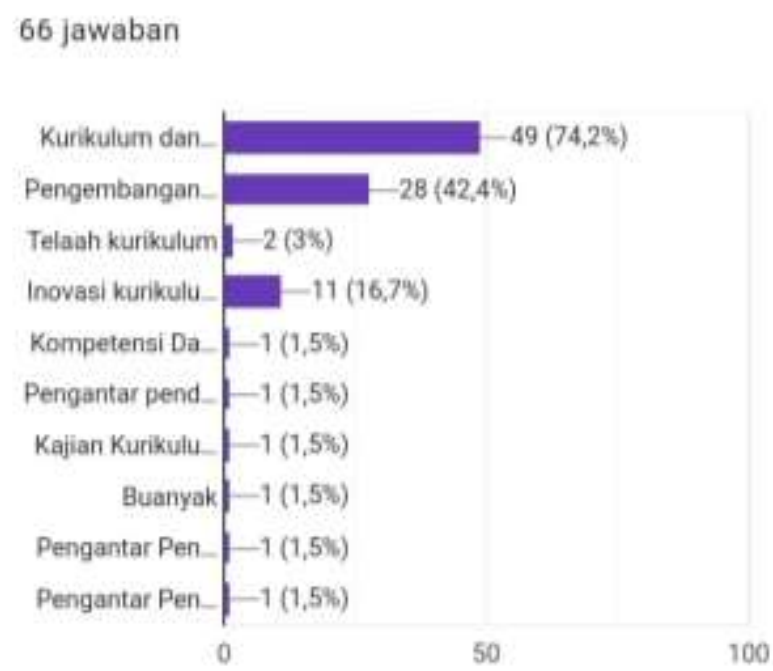

\section{Gambar 1. Mata kuliah yang pernah ditempuh mahasiswa}

Berdasarkan Gambar 1 diketahui matakuliah kurikulum dan pembelajarannya dipilih responden sebanyak $74 \%$, artinya sebagian besar responden pernah menempuh matakuliah tersebut. Selanjutnya ada matakuliah pengembangan kurikulum yang mendapat respon sebanyak $42 \%$. Disusul mata kuliah Inovasi Kurikulum yang mendapatkan respon sebesar 16,7\% kemudian mata kuliah Telaah Kurikulum yang mendapat respon sebesar 3\%. Sedangkan yang lainnya mendapat respon yang jauh lebih sedikit dari pada keempat mata kuliah tersebut. Penamaan mata kuliah tergantung oleh kebijakan kurikulum yang dianut oleh suatu Universitas. Selain itu visi misi fakultas dan program studi juga turut mempengaruhi perencanaan dan penamaan suatu mata kuliah yang akan diajarkan kepada mahasiswa (Fujiawati 2016). Sehingga mungkin ada perbedaan nama mata kuliah pada suatu universitas dengan universitas lain meskipun materi yang disajikan hampir sama.

\section{Hal apa saja yang menjadi kendala dalam perkuliahan kurikulum?}

66 jawaban

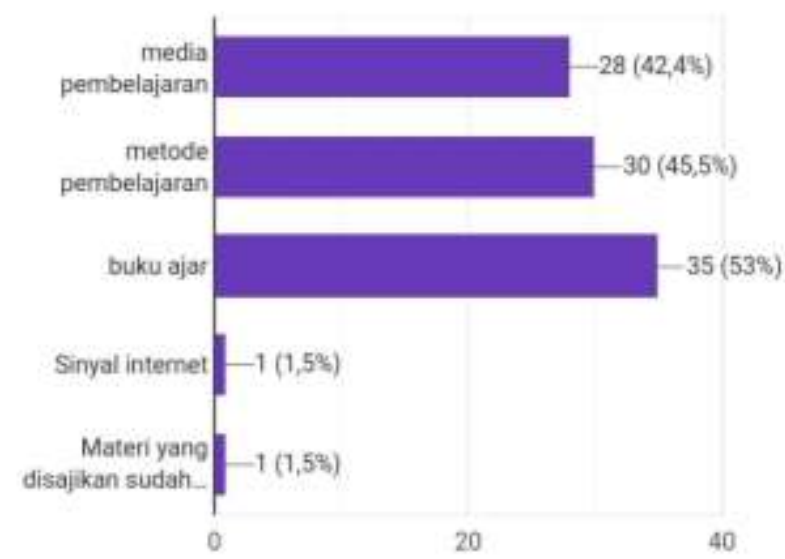

Gambar 2. Kendala-kendala dalam perkuliahan kuruikulum 
Berdasarkan Gambar 2 diketahui bahwa kendala terbesar dalam perkuliahan kurikulum adalah pengadaan buku ajar yang mendapat respon sebanyak 53\%. Buku ajar merupakan buku yang disusun secara sistematis pada bidang ilmu tertentu dan ditulis oleh seorang penulis sesuai bidang ilmu tersebut guna melengkapi sumber belajar (Suwartini 2018). Buku ajar merupakan salah satu komponen penting dalam proses pembelajaran. Meski buku ajar bukanlah satu-satunya sumber belajar, namun dengan adanya buku ajar ini akan mempermudah mahasiswa dalam memahami materi yang disampaikan oleh dosen. Oleh sebab itu perlu dikembangkan buku ajar yang sesuai dengan kebutuhan mahasiswa. Komponen lain yang menjadi kendala dalam perkuliahan kurikulum adalah metode pembelajaran yang mendapat prosentase responden sebesar 45,5\%. Metode pembelajaran sangat mempengaruhi alur perkuliahan yang disajikan oleh seorang dosen. Metode pembelajaran dengan alur yang jelas akan menunjukkan langkah demi langkah yang harus dilakukan selama perkuliahan berlangsung baik perkuliahan dalam kelas maupun secara mandiri atau tugas mandiri (Dewi 2018). Kemudian kendala lain selain keterbatasan buku ajar dan metode pembelajaran adalah media pembelajaran dengan jumlah prosentase responden sebesar 42,4\%. Sama seperti buku ajar dan metode pembelajaran, media pembelajaran memiliki peran untuk mempermudah seorang dosen menyampaikan materi yang diajarkan. Pemilihan media pembelajaran yang tepat yakni disesuaikan dengan materi pembelajaran sangat mempengaruhi ketercapaian tujuan pembelajaran (Ma'rifah and Sumadi 2016). Selain itu keterampilan seorang pengajar dalam menggunakan dan menyajikan suatu media pembelajaran akan mempengaruhi pemahaman mahasiswa dalam memahami suatu materi perkuliahan (Ma'rifah and Sumadi 2016). Kendala lain yang mendapat prosentase paling sedikit yakni 1,5\% adalah sinyal internet dan materi yang ada. Sinyal internet merupakan kendala dalam perkuliahan secara online. Kekuatan sinyal provider pada tiap-tiap daerah berbeda, sehingga sulit untuk menyamakan kondisi tiap individu karena hal ini termasuk masalah yang tidak terprediksi (Putri and Suyadi 2021). Di sisi lain masalah pada penyajian materi perkuliahan menjadi masalah terkecil dalam perkuliahan karena dapat diatasi dengan mempersiapkan materi perkuliahan sejak awal semester dan sudah dirancang secara detail pada RPS (Rencana Perkuliahan Semester).

\section{Sumber belajar apa sajakah yang Saudara gunakan untuk mempelajari kurikulum ?}

\section{6 jawaban}

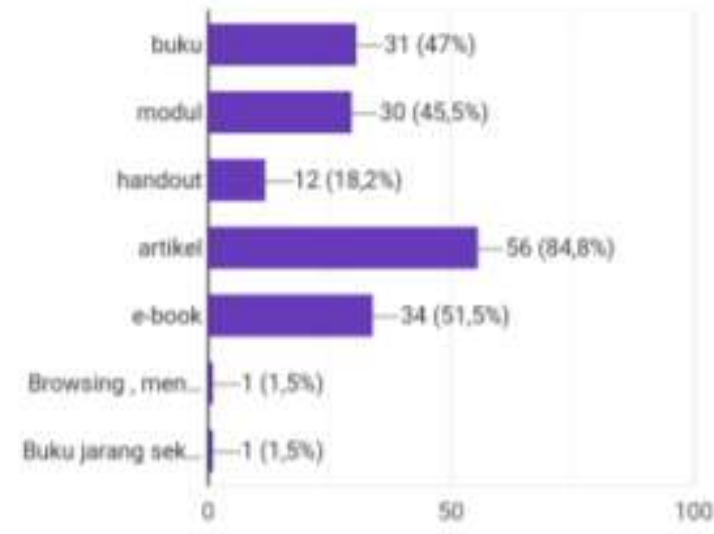

\section{Gambar 3. Sumber belajar pada perkuliahan Kurikulum}

Sumber belajara merupakan salah satu komponen penting dalam menunjang perkuliahan. Dengan menggunakan sumber belajar yang tepat akan membantu mahasiswa untuk dapat memahami materi yang disampaikan oleh dosen serta dapat melakukan kuliah mandiri diluar jam perkuliahan yakni mengerjakan tugas mandiri (Hafid 2011). Menurut responden sebesar 84,8\% mahasiswa selama perkuliahan sering menggunakan artikel berupa jurnal online, majalah ilmiah dan artikel web sebagai sumber belajar mereka. Artikel menjadi sumber belajar terbesar karena updatenya yang cepat dan cara mengaksesnya yang sangat 
mudah (Supriadi 2015), sehingga banyak mahasiswa merasa tidak perlu repot-repot untuk pergi keperpustakaan untuk mencari sumber belajar. Selanjutnya ada e-book yang menurut $51,5 \%$ responden menjadi sumber belajar yang diminati. E-book merupakan sebuah buku elektronik (buku digital). Versi digital pada buku ajar memang sudah banyak ditemui pada saat ini, dengan adanya $e$-book para mahasiswa tidak perlu repot-repot untuk keluar rumah untuk mencari hard book yang dibutuhkan. E-book merupakan salah satu kecanggihan teknologi untuk mempermudah proses pembelajaran (Jannah, Fadiawati, and Tania 2017). Disisi lain hard book atau buku mendapat jumlah respon sebesar 47\%. Meski e-book banyak diminati mahasiswa karena kemudahan dalam mengaksesnya, namun masih ada mahasiswa yang termotivasi datang ke perpustakaan untuk sekedar membaca buku atau meminjam buku yang akan digunakan sebagai sumber belajarnya.

Tidak kalah dari buku, ada modul yang mendapat respon sebesar $45,5 \%$ sebagai sumber belajar yang diminati oleh mahasiswa. Memang tidak semua perkuliahan dilengkapi modul, karena modul yang baik adalah yang dapat dikembangkan oleh dosen pengampu agar materi dan penugasan yang disajikan sesuai dengan tujuan perkuliahan sesuai isi RPS (Stewart and Wilkerson 2013). Modul merupakan sebuah bahan ajar yang dikembangkan sesuai kebutuhan belajar. Isi dalam modul berupa materi ajar, ringkasan, tugas pendalaman, soal evaluasi dan refleksi (Sari, Abadi, and Nawawi 2021). Bahan ajar lain yang dapat dikembangkan oleh dosen pengampu selain modul adalah handout. Handout merupakan rangkaian ringkasan materi berasal dari berbagai sumber yang relevan dengan kompetensi dasar yang dibuat oleh pengajar dengan tujuan mempermudah siswa dalam memahami suatu materi pembelajaran (Habibati, Nazar, and Septiani 2019).

\section{Apakah referensi dan bahan ajar yang ada saat ini sudah memenuhi kebutuhan Saudara/i dalam memahami kajian tentang kurikulum?}

Pada pertanyaan keempat ini merupakan pertanyaan terbuka untuk responden. Sekitar 35 responden menyatakan bahan ajar yang digunakan dosen kurang memenuhi kebutuhan belajar mahasiswa. Hal ini terjadi karena bahan ajar yang disajikan dosen pengampu pada umumnya hanya berupa power point dan untuk melengkapi itu dosen pengampu menyertakan beberapa referensi buku untuk dijadikan sumber belajar secara mandiri. Namun selain referensi yang diberikan dosen pengampu, mahasiswa ternyata sering mencari sumber belajar lain dari internet. Sumber belajar tersebut dapat berupa jutnal online ataupun artikel ilmuah lainnya. Selanjutnya sekitar 26 mahasiswa merasa bahan ajar yang digunakan dosen pengampu sudah memenuhi kebutuhan belajar mahasiswa. Adapun hal yang mempengaruhi mahasiswa merasa cukup dengan bahan ajar yang disajikan dosen pengampu adalah mahasiswa merasa bahan ajar yang disajikan dosen pengampu sudah tepat dan sesuai dengan point-point materi yang diajarkan. Terlepas dari kebutuhan bahan ajar sudah mememenuhi atau belum dengan kebutuhan belajar mahasiswa, alangkah baiknya dosen pengampu dapat mengembangkan bahan ajar sendiri sesuai matakuliah yang diampu. Kelebihan dalam mengembangkan bahan ajar mandiri adalah sumber belajar yang didapat mahasiswa sesuai dengan ranah materi yang diajarkan oleh dosen pengampu, sehingga menunjang dalam mencapai tujuan perkuliahan yang telah direncanakan sebelumnya (Mukmin and Zunaidah 2018).

\section{Jika ada pengembangan bahan ajar untuk mata kuliah tentang kurikulum, kriteria bahan ajar seperti apa yang Saudara/i inginkan? Sebutkan}

Pada bagian ini menyajikan jawaban para responden yang sangat beragam terkait kreteria bahan ajar yang diinginkan atau yang sesuai dengan kebutuhan mahasiswa. Kreteria yang diinginkan oleh para responden yakni bahan ajar disesuaikan dengan materi yang disajikan oleh dosen pengampu. Isi materi dalam bahan ajar sesuai dengan urutan materi yang disampikan oleh dosen pengampu dan terdapat penjabaran materi atau point penting untuk menambah wawasan baru serta menambah pemahaman mahasiswa terkait kurikulum (Saidah 2019). Selain itu bahan ajar disajikan dengan praktis, mudah digunakan dimanapun dan kapan pun. Bahan ajar 
DOI: https://doi.org/10.31004/basicedu.v5i6.1802

dapat disajikan dalam bentuk e-book agar dapat diakses dengan mudah dan fleksibel. Bahan ajar dapat dilengkapi dengan ringkasan materi untuk mereview materi yang sudah disajikan. Selain itu dapat pula dilengkapi dengan sebuah studi kasus dan Latihan soal untuk memperdalam pemahaman mahasiswa pada tiap materi yang disajikan dalam bahan ajar.

\section{Topik apa saja yang perlu ada dalam bahan ajar mata kuliah tentang kurikulum? Sebutkan}

Secara garis besar, topik yang diinginkan responden yang terdapat pada bahan ajar kurikulum sama dan runtut dengan yang disajikan oleh dosen pengampu. Keruntutan penyajian materi disesuaikan dengan rencana yang sudah tertulis dalam RPS. Topik-topik yang perlu untuk disajikan menurut responden yakni 1) Pengertian kurikulum, 2) Fungsi kurikulum, 3) Prinsip dan tujuan kurikulum, 4) Komponen kurikulum, 5) Asas-asas kurikulum, 6) Model-model kurikulum dan pengembangannya, 7) Pengembang kurikulum serta 8) Hambatan-hambatan dalam pengembangan kurikulum. Topik-topik tersebut umum disajikan pada beberapa jenis matakuliah kurikulum dan dianggap sebagai dasar dalam memahami sebuah kurikulum bagi seorang calon guru (Endah and Hendrastomo 2017).

\section{Bagaimana kriteria penyajian materi kurikulum dalam buku ajar yang Saudara/i butuhkan? Sebutkan}

Materi dalam sebuah bahan ajar harus disajikan dengan baik agar mudah dipahami oleh mahasiswa. Adapun kreteria penyajian materi yang diinginkan oleh responden adalah disusun secara sistematis mulai dari materi dasar sampai pendalaman. Kemudian materi disajikan singkat dan tepat. Materi yang disajikan tepat pada tujuan perkuliahan yang ada. Materi disajikan dengan menggunakan bahasa yang ringan. Penggunaan bahasa yang disesuaikan dengan tingkat pemahaman mahasiswa akan mempermudah mahasiswa dalam memahami suatu materi perkuliahan. Adapun istilah asing yang disajikan dalam bahan ajar dapat ditandai dan dijelaskan maknanya. Tidak kalah pentingnya, materi sebaiknya dilengkapi dengan ringkasan materi. Hal ini digunakan untuk mereview kembali materi yang telah dibaca agar lebih mudah untuk memahaminya. Materi juga dilengkapi ilustrasi dan kontras warna yang manarik agar dapat membangkitkan motivasi belajar mahasiswa. Sebagaimana yang diungkapkan dalam Prastowo (2014) bahwa kriteria bahan ajar yang baik itu menggunakan bahasa yang mudah dimengerti, menyajikan materi dengan gambar yang menarik dan lengkap dengan keterangannya, serta materinya disesuaikan dengan kurikulum yang berlaku.

\section{Latihan atau studi kasus seperti apa yang sesuai dalam mata kuliah kurikulum?}

Selain materi dalam sebuah bahan ajar juga dapat dilengkapi dengan latihan atau studi kasus terkait materi yang disajikan. Menurut responden, latihan atau studi kasus yang disajikan hendaknya disesuaikan dengan permasalahan dalam sebuah pengimplementasian kurikulum yang sering ditemui dilapangan. Kasus yang disajikan dapat beasal dari lingkup daerah asal atau kasus yang bersifat global yang menjadi tranding secara global. Latihan atau studi kasus ini dapat membantu mahasiswa untuk dapat lebih memahami materi dan dapat mencari kaitannya dalam sebuah kasus yang terjadi di masyarakat (Sinambela and Sinaga 2020).

\section{Apa saran saudara untuk pengembangan bahan ajar kurikulum agar mudah memahami kurikulum dan implementasinya?}

Pertanyaan terakhir yang menjadi point penting pada analisis kebutuhan ini adalah bahan ajar kurikulum yang diharapkan responden. Responden sangat membutuhakn bahan ajar yang sesuai dengan materi yang disajikan oleh dosen pengampu, baik secara isi maupun dalam menunjang latihan atau tugas mandiri mahasiswa. Bahan ajar dapat disajikan secara sistematis dari teori dasar sampai teori pendalaman terkait kurikulum. Materi dalam bahan ajar disajikan secara menarik dan menggunakan Bahasa yang mudah dipahami. Selain itu bahan ajar juga hendaknya dilengkapi dengan latihan atau studi kasus untuk 
DOI: https://doi.org/10.31004/basicedu.v5i6.1802

memperdalam pemahaman materi dan menambah wawasan mahasiswa terkait kurikulum yang diimplementasikan saat ini. Dan tidak kalah pentingnya adalah bahan ajar harus simple dan fleksibel sehingga tidak hanya digunakan pada perkuliahan tatap muka saja, namun dapat diakses kapan pun dan dimana pun (Anggraini et al. 2020) .

\section{KESIMPULAN}

Berdasarkan hasil dan pembahasan yang berasal dari angket kebutuhan, diketahui bahwa 1) mahasiswa membutuhkan sebuah bahan ajar berupa buku ajar untuk menunjang proses perkuliahan pada mata kuliah kurikulum, 2) bahan ajar menyajikan topik-topik sesuai dengan yang disajikan dosen pengampu, 3) bahan ajar disajikan secara sistematis, menarik dan menggunakan Bahasa yang mudah dipahami oleh mahasiswa dan 4) bahan ajar bisa bersifat fleksibel bisa diakses kapan pun dan dimanapun. Diharapkan dengan adanya hasil angket kebutuhan bahan ajar matakuliah kurikulum ini dapat dijadikan dasar dalam mengembangkan bahan ajar yang disesuaikan dengan kebutuhan mahasiswa.

\section{UCAPAN TERIMA KASIH}

Terima kasih kepada para mahasiswa Universitas Islam Balitar dan Universitas Nusantara PGRI Kediri yang berkenan memberikan pendapatnya pada angket kebutuhan bahan ajar pada mata kuliah kurikulum ini. terima kasih pada semua pihak yang terlibat dalam penyusunan artikel jurnal ini. Semoga artikel jurnal ini dapat bermanfaat untuk penelitian selanjutnya.

\section{DAFTAR PUSTAKA}

Anggraini, Vina, Syahrul, Darnis Arief, And Maistika Ratih. 2020. "Pengembangan Bahan Ajar Membaca Sastra Berbasis Graphic Organizer Venn Diagram Di Sekolah Dasar.” Jurnal Basicedu 4(4):1219-27. Doi: Https://Doi.Org/10.31004/Basicedu.V4i4.513.

Dewi, Erni Ratna. 2018. "Metode Pembelajaran Modern Dan Konvensional Pada Sekolah Menengah Atas." Pembelajar: Jurnal Ilmu Pendidikan, Keguruan, Dan Pembelajaran 2(1):44. Doi: 10.26858/Pembelajar.V2i1.5442.

Endah, Nur, And Grendi Hendrastomo. 2017. "Implementasi Pendidikan Karakter Melalui Perkuliahan Etika Dan Profesi Keguruan.” Jurnal Pendidikan Karakter 7(2):240-54.

Fujiawati, Fuja Siti. 2016. "Pemahaman Konsep Kurikulum Dan Pembelajaran Dengan Peta Konsep Bagi Mahasiswa Pendidikan Seni." Jpks (Jurnal Pendidikan Dan Kajian Seni) 1(1):16-28. Doi: Http://Dx.Doi.Org/10.30870/Jpks.V1i1.849.

Habibati, Muhammad Nazar, And Putri Dewi Septiani. 2019. "Pengembangan Handout Berbasis Literasi Sains Pada Materi Larutan Elektrolit Dan Nonelektrolit." Jurnal Ipa Dan Pembelajaran Ipa (Jipi) 3(1):36-41. Doi: Https://Doi.Org/10.24815/Jipi.V3i1.13824.

Hafid, Abd. 2011. "Sumber Dan Media Pembelajaran.” Sulesana Jurnal Wawasan Keislaman 6(2):69-78. Doi: Https://Doi.Org/10.24252/.V6i2.1403.

Irawati, Hani, And Much. Fuad Saifuddin. 2018. "Analisis Kebutuhan Pengembangan Bahan Ajar Mata Kuliah Pengantar Profesi Guru Biologi Di Pendidikan Biologi Universitas Ahmad Dahlan Yogyakarta." Biopedagogi: Jurnal Pembelajaran Biologi 7(2):96-99. Doi: Https://Doi.Org/10.20961/BioPedagogi.V7i2.27636.

Jannah, Naimatil, Noor Fadiawati, And Lisa Tania. 2017. "Pengembangan E-Book Interaktif Berbasis Fenomena Kehidupan Sehari-Hari Tentang Pemisahan Campuran." Jurnal Pendidikan Dan 
6226 Analisis Kebutuhan Bahan Ajar Mata Kuliah Kurikulum - Eva Nurul Malahayati, Farida Nurlaila Zunaidah

DOI: https://doi.org/10.31004/basicedu.v5i6.1802

Pembelajaran Kimia 6(1):186-98.

Julaeha, Siti. 2019. "Problematika Kurikulum Dan Pembelajaran Pendidikan Karakter." Jurnal Penelitian Pendidikan Islam 7(2):157-82. Doi: Https://Doi.Org/10.36667/Jppi.V7i2.367.

Lilawati, Jenny. 2017. “Analisis Pemanfaatan Sumber Belajar Dalam Proses Pembelajaran.” In Seminar Nasional Tahunan Fakultas Ilmu Sosial Universitas Negeri Medan Tahun 2017. Digital Repository Universitas Negeri Medan.

Ma'rifah, Mufti, And Sumadi. 2016. "Pengaruh Penerapan Media Power Point." Ilmiah Pendidikan Fisika 3(1):96-103.

Mukmin, Bagus Amirul, And Farida Nurlaila Zunaidah. 2018. "Pengembangan Bahan Ajar Delikan Tematik Berbasis Multimedia Interaktif Untuk Siswa Sekolah Dasar Di Kota Kediri." Al Ibtida: Jurnal Pendidikan Guru Mi. Doi: 10.24235/Al.Ibtida.Snj.V5i2.2788.

Prasetiyo, Nugroho Aji, And Pertiwi Perwiraningtyas. 2017. "Pengembangan Buku Ajar Berbasis Lingkungan Hidup Pada Matakuliah Biologi Di Universitas Tribhuwana Tunggadewi.” Jurnal Pendidikan Biologi Indonesia 3(1):19-27.

Putri, Ragil Dian Purnama, And Suyadi Suyadi. 2021. "Problematika Pembelajaran Daring Dalam Penerapan Kurikulum 2013 Tingkat Sekolah Dasar.” Jurnal Basicedu 5(5):3912-19. Doi: Https://Doi.Org/10.31004/Basicedu.V5i5.1442.

Saidah, Karimatus. 2019. "Pengembangan Bahan Ajar Materi Dongeng Berbasis Kearifan Lokal Jawa Timur Bagi Siswa Kelas Iii Sd.” Premiere Educandum : Jurnal Pendidikan Dasar Dan Pembelajaran 9(1):73. Doi: 10.25273/Pe.V9i1.4320.

Sari, Ike Puspita, Suyud Abadi, And Sulton Nawawi. 2021. "Pengembangan Modul Pembelajaran Biologi Berbasis Problem Solving Pada Materi Ekologi." Best Journal (Biology Education, Sains And Technology) 4(1):25-31.

Sasmita, Rimba Sastra. 2020. "Pemanfaatan Internet Sebagai Sumber Belajar." Jurnal Pendidikan Dan Konseling (Jpdk) 2(1):99-103. Doi: Https://Doi.Org/10.31004/Jpdk.V1i2.603.

Setiawan, Beni, And Olenggius Jiran Dores. 2019. "Pengembangan Bahan Ajar Berbasis Keterampilan Metakognisi Dalam Upaya Meningkatkan Kemampuan Literasi Matematis Mahasiswa." Jurnal Pendidikan Matematika Indonesia 4(2):68-72. Doi: Https://Doi.Org/10.26737/Jpmi.V4i2.1412.

Sinambela, Masdiana, And Tonggo Sinaga. 2020. "Pengembangan Bahan Ajar Biologi Umum Sebagai Sumber Belajar Untuk Buku Peganggan Mahasiswa.” Jurnal Pelita Pendidikan 8(3):189-94. Doi: 10.24114/Jpp.V8i3.19988.

Stewart, Joanne L., And Valorie L. Wilkerson. 2013. A Guide To Teaching With Modules. Hope Collage: Washington Dc.

Sudrajat, Tatang, Omay Komarudin, Ni'mawati Ni’mawati, And Qiqi Yuliati Zaqiah. 2020. "Inovasi Kurikulum Dan Pembelajaran Pada Masa Pandemi Covid-19." Jurnal Ilmiah Wahana Pendidikan 6(3):317-47. Doi: Https://Doi.Org/10.5281/Zenodo.3960178.

Supriadi. 2015. "Pemanfaatan Sumber Belajar Dalam Proses Pembelajaran.” Lantanida Journal 3(2):127-39. Doi: Http://Dx.Doi.Org/10.22373/Lj.V3i2.1654.

Suwartini, Sri. 2018. "Pengembangan Buku Ajar Pendidikan Karakter Dengan Pendekatan Pembelajaran Berbasis Soft Skill Pada Siswa Sd Kelas Ii." Jurnal Educhild 7(2):102-6.

Wulandari, Yosi, And Wachid E. Purwanto. 2017. "Kelayakan Aspek Materi Dan Media Dalam Pengembangan Buku Ajar Sastra Lama." Jurnal Gramatika Jurnal Penelitian Pendidikan Bahasa Dan Sastra Indonesia 3(2):162-72. Doi: Http://Dx.Doi.Org/10.22202/Jg.2017.V3i2.2049. 